\title{
EXPLOITATION OF SELECTED RAILWAY EQUIPMENT - CONDUCTED DISTURBANCE EMISSION EXAMINATION
}

\author{
Kamil BIALEK ${ }^{1}$, Jacek PAŚ ${ }^{2}$ \\ ${ }^{1}$ Railway Institute, Signalling and Telecommunication Laboratory, Chłopickiego 50, \\ 04-275 Warsaw, e-mail: kbialek@ikolej.pl \\ ${ }^{2}$ Military University of Technology, Faculty of Electronic, gen. Witolda Urbanowicza 2, \\ 00-908 Warsaw, e-mail: jacek.pas@wat.edu.pl
}

\begin{abstract}
The parameter of interference signals that determines the type of coupling is a frequency of interference signals. For the frequencies lower than $30 \mathrm{MHz}$, the conducted disturbances are dominant, however, for the higher frequencies, the signals transmitted by the electromagnetic field - radiated disturbances - becomes more and more important. The article presents the potential sources of interference occurring in the railway environment and discusses the methods of their elimination. The authors of the article carried out the measurements of conducted disturbances for two pieces of railway equipment - i.e. an information board and a DC/DC static converter. The paper includes the example results of normative measurements before and after the installation of a filter that eliminates the excessive levels of disturbances.
\end{abstract}

Keywords: conducted disturbances, exploitation, electromagnetic interference.

\section{EKSPLOATACJA WYBRANYCH URZĄDZEŃ KOLEJOWYCH - POMIAR EMISJI ZABURZEŃ PRZEWODZONYCH}

Streszczenie

Parametrem sygnałów zakłócających decydującym o rodzaju sprzężenia, jest częstotliwość sygnałów zakłócających. Dla częstotliwości mniejszych od $30 \mathrm{MHz}$ dominującymi są zakłócenia przewodzone, natomiast dla częstotliwości wyższych znaczenia nabierają sygnały przenoszone przez pole elektromagnetyczne - zakłócenia promieniowane. W artykule przedstawiono potencjalne źródła zakłóceń występujące w środowisku kolejowym oraz omówiono sposoby ich eliminacji. Autorzy artykułu przeprowadzili pomiary zaburzeń przewodzonych dla dwóch urządzeń kolejowych - tj. tablica informacyjna i przetwornica statyczna DC/ DC. W referacie zamieszczono przykładowe wyniki normatywnych pomiarów przed zainstalowaniem filtru eliminującego nadmierne poziomy zaburzeń jak i po instalacji.

Słowa kluczowe: zaburzenia przewodzone, eksploatacja, zakłócenia elektromagnetyczne.

\section{INTRODUCTION}

The parameter of interference signals that determines the type of coupling is a frequency of interference signals. For the frequencies lower than $30 \mathrm{MHz}$, the conducted disturbances are dominant, however, for the higher frequencies, the signals transmitted by the electromagnetic field - radiated disturbances - become more and more important [1, $22,25,27]$. In the railway area, the electromagnetic interference can be generated by two circuits high- and low-current ones.

Figure 1 presents a model of the impact of the conducted and radiated disturbance sources, which are generated in a vast railway area. Railway vehicles $\mathrm{X} 1, \mathrm{X} 2, \ldots \mathrm{Xn}$ are powered with a DC voltage of $3 \mathrm{kV}$ from the overhead contact line.

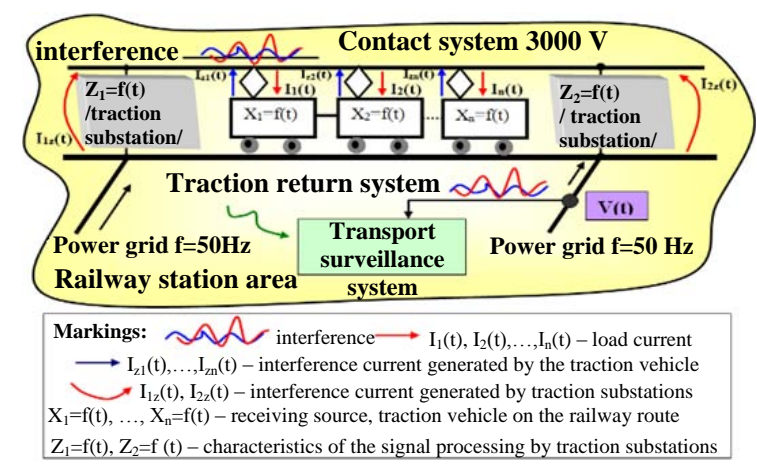

Fig. 1. Model of the impact of stationary and mobile interference on the railway route

The vehicles charge the load current $I_{1}(t)$, $I_{2}(t), \ldots, I_{n}(t)$, the value of which is variable in time and it is a function of many variables, e.g. movement of vehicles on the route - e.g. braking, start, acceleration, power of drive motors, the technical condition of contacts, etc. - Fig. 1. 
At the same time, traction vehicles generate interference currents $I_{z}(t), I_{z}(t), \ldots, I_{z}(t)$, which propagate in lines through the overhead contact line to the power substation $Z_{1}=f(t), Z_{2}=f(t)-$ Fig. 1 . Variable load disturbances of individual railway vehicles interact with harmonics of the power grid supplying the substations $(110 \mathrm{kV})$ and variable voltage components of DC rectifiers of individual traction substations $[17,19,20,21,23,26]$. In the power grid, which supplies the vast railway area as a result of the impact of various power consumption sources (traction vehicles, rail traffic management systems, transport surveillance systems, etc.) with various characteristics of the input signal processing, a fairly wide spectrum of interference is generated. The railway environment is one of the most difficult environments in terms of ensuring the electromagnetic compatibility. The compatibility is defined as acceptable conditions for the impact of electromagnetic external and internal fields on the operation of electronic devices and equipment containing electronic systems. In accordance with the provisions occurring in the international standard IEC 50 (161) of 1990 included then in the project of the Polish Standard Pr. PN-T-01030, it is assumed that: "electromagnetic compatibility is the capability of the device or system to operate satisfactorily in the specific electromagnetic environment, also without introducing unacceptable electromagnetic disturbances into this environment" [1]. The railway environment is characterized by the following features:

1. large areal extent and various methods of the power supply solution (AC, DC);

2. power, signal, control and telecommunication cables are laid together or very close to each other, which is a reason for the induction of interference signals in the systems (length of power cables, communication buses can reach a value of several kilometres) $[1,8,21,23,25,26]$;

3 . coexistence of circuits, high- and low-voltage devices drawing low and very high supply currents $[1,3,10]$;

4. complexity and interconnection of subsystems of different generation subsystems - including electronic safety systems $[2,7,9]$;

5. variety of power supply systems and their configuration (from DC voltage to AC voltage with different frequencies);

6. extensive, unintentional, mobile electromagnetic energy sources with a high level of disturbances in time;

7. transfer of power to the trains by sliding contacts, which constitute an element of the system generating the interference with a wide spectrum of frequencies;

8. asymmetrical loads in individual voltage phases $\left(\mathrm{L}_{1}, \mathrm{~L}_{2}, \mathrm{~L}_{3}\right)$ supplying the railway building and electric traction;

9. variable and simultaneous generation of disturbances from many sources which may lead to interference, resonance, addition, subtraction or multiplication of interference - Fig. 2 .

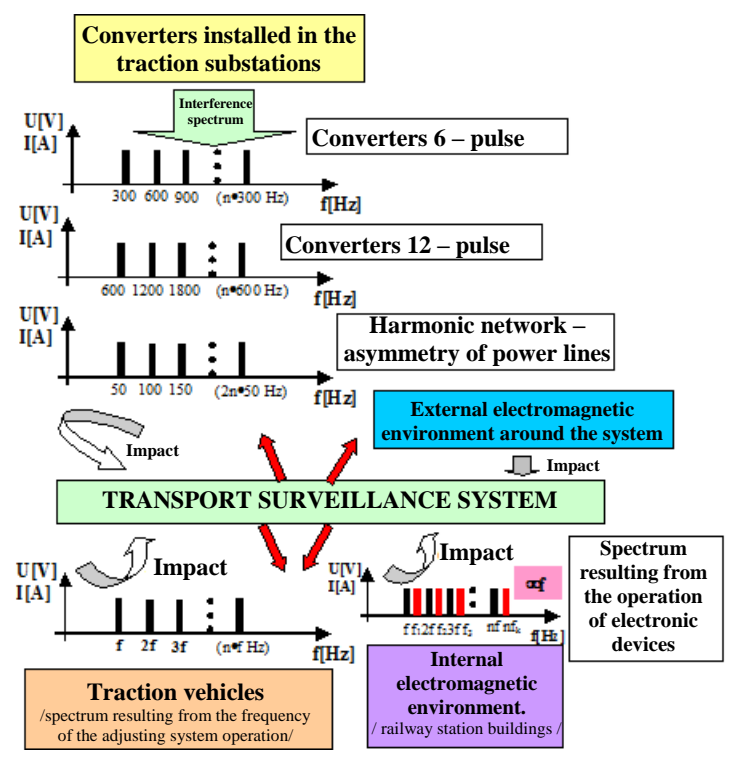

Fig. 2. Sources of interference affecting the electronic systems installed in the vast railway area

Due to non-linearity of transient characteristics of elements, devices used in the electronic systems that are installed in the vast railway area, it is important to take into account the occurrence of intermodulation distortions $[1,10,11]$.

\section{GROUNDING AND SHIELDING TECHNIQUES}

The correct transmission, processing and use of electrical signals in the railway equipment require the existence of equipotential points and/or planes (potentials fixed in time, independent of the value of sink or source currents). These reference points or planes in a given subassembly, device or railway system constitute the so-called ground (also known as the grounds of signals). The name of grounding is fully adequate in case of the situation when a point or a given plane is on the earth potential (there is a physical connection with the earth). The points and planes located on the ground potential are safe for a human being. In practice, the reference points or planes are not equipotential the grounding has low non-zero impedance (resistance). Then, the ground loops are formed in the electric and electronic circuits of railway equipment. If the signal source and the receiver (e.g. load - e.g. a battery pack in the railway vehicle) are connected to such a reference plane in the sufficiently distant points, then, a difference in potentials arises between these points, as a result of which the current flowing in this circuit occurs. If multiple signal and load sources were connected to one plane or point, numerous, also common, return paths are formed, through which the currents flow from the loads to the sources. Then, there is a 
mutual undesirable phenomenon - the interference effect of circuits. Then, the plane points references have different potentials. If we consider two points, which are placed at the distance of $1 \mathrm{~m}$ on the metal plane (conductive housing of the railway vehicle) that constitutes a reference plane for operating signals, then, between these points there will be a difference in $U$ potentials for a given $f$ frequency caused by e.g. the impact of the unintentional magnetic field, which is generated by the power cable e.g. of the converter. The impedance $\mathrm{Z}$ between these two points can be recorded with the relationship (1)

$$
Z \approx R=R_{R F}\left(1+\frac{\operatorname{ltg} 2 \Pi l}{\lambda l}\right) \cdot \frac{l}{w}
$$

The impedance value depends on the frequency (wavelengths $\lambda$ ) of interference occurring in the railway equipment. For different frequency ranges, $\mathrm{Z}$ impedance can be described with the use of the expressions (2-4)

$$
\begin{gathered}
Z \cong R_{R F}\left(1+\frac{2 \Pi l}{\lambda l}\right) \cdot \frac{l}{w} \cong k \cdot R_{D C}\left(1+\frac{2 \Pi l}{\lambda}\right) \cdot \frac{l}{w} \text { dla } l<\frac{\lambda}{10} \\
Z \cong R_{R F} \cdot \frac{l}{w} \cong k \cdot R_{D C} \cdot \frac{l}{w} \text { dla } l<\frac{\lambda}{20} \\
Z \cong R_{R F} \cdot \frac{2 l}{w} \cong 2 k \cdot R_{R F} \cdot \frac{l}{w} \text { dla } l \approx \frac{\lambda}{8}
\end{gathered}
$$

where:

$R_{R F}[\Omega]$ - surface resistance for the alternating current, $R_{R F}=0.26 \cdot 10^{-6} \sqrt{f}$ for copper,

$R_{R F}=0.26 \cdot 10^{-6} \sqrt{\mu_{w} \cdot f} / \sigma_{w}$ for other metals,

$\sigma_{\mathrm{w}}$ - relative conductivity of the metal related to copper, $\mu_{\mathrm{w}}-$ relative permeability of the metal related to copper, $\lambda[\mathrm{m}]$ - wavelength corresponding to the frequency of the interference field,

$R_{D C}[\Omega]$ - surface resistance of the direct current $\mathrm{k}$ - number indicating the value $R_{R F} / R_{D C}$.

The relationships 1-4 will make it possible to estimate the impedance of the ground planes of various sizes, made of different metals for various frequencies of interference signals. The relationship 1 results in the fact that in practice, the impedance between two points on the equipotential plane may have different values. For the reference plane made of the metal with the following electrical properties $\left(\sigma_{w}=10^{-1}, \mu_{w}=10^{3}\right)$ and the dimensions of $1=70$ $\mathrm{cm}$, width $\mathrm{w}=1 \mathrm{~cm}, \mathrm{Z}$ value between extreme points on the plane for the interference frequency $\mathrm{f}$ $=100 \mathrm{kHz}(\lambda=3 \mathrm{~km})$ can be estimated with the use of the relationship 3 . The relationship shows that $1 / \lambda=2,3 \cdot 10^{-4}<1 / 20$. The impedance $Z$ for this case will be

$$
Z \cong R_{R F} \cdot \frac{l}{w}=0,57 \Omega
$$

The circuit No. 1 is the source of interference, the electronic safety system is an interference receiver, and the interference signal is transferred by the common reference plane characterised by $\mathrm{Z}$ impedance. be

By analysing the circuit No. $1, \mathrm{U}_{\mathrm{z}}$ voltage will

$$
U_{Z}=E_{1} \frac{Z}{R_{S 1}+R_{O 1}+Z}
$$

The circuit No. 2 is a receiver of interference, the interference component on the resistance $\mathrm{R}_{\mathrm{o} 2}$

$$
U_{z o 2}=U_{Z} \frac{R_{O 2}}{R_{S 2}+R_{O 2}+Z}
$$

The voltage of interference for the circuit 2 will be

$$
U_{z o 2}=E_{1} \frac{Z R_{O 2}}{\left(R_{S 1}+R_{O 1}\right)\left(R_{S 2}+R_{O 2}\right)}
$$

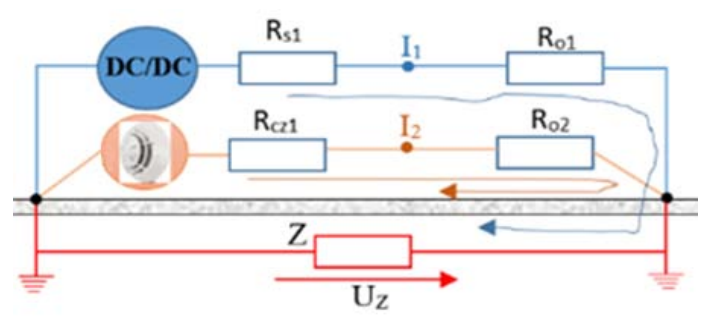

Fig. 3. The phenomenon of interference caused by the coupling of circuits with different levels of the signal on the common impedance $\mathrm{Z}$ of the ground plane: where: $R_{\mathrm{s} 1}, R_{\mathrm{s} 2}-$ internal resistance of DC/DC converter source and the electronic safety system detectors, $\mathrm{R}_{\mathrm{s} 1}, \mathrm{R}_{\mathrm{s} 2}$ - load resistance of the converter circuit and the safety system detectors

\section{EMISSION OF CONDUCTED DISTURBANCES BY THE SELECTED RAILWAY EQUIPMENT - INFORMATION BOARD}

The equipment placed on the European market should meet certain standards of the electromagnetic compatibility (EMC). Meeting the normative requirements guarantees that the device will not interfere the operation of other electronic devices nearby and it will be resistant to the surrounding electromagnetic disturbances $[16,18]$.

The article presents two examples of reduction of disturbances of the emission conducted by the selected railway equipment.

The first example is an interactive information board mounted at the platforms, tram and bus stops. It is designed for displaying current information about traffic on the transport route - i.e. departures and arrivals of trains, trams and buses. The board is equipped with a communication module, a system of speakers and a service card reader. The measurement of the emission of conducted disturbances was carried out in accordance with PN-EN 55016-2-1 standard [12] in the frequency range from $15 \mathrm{kHz}$ to $30 \mathrm{MHz}$ for $230 \mathrm{~V}$ AC lowvoltage power grid. The acceptable levels of disturbances result from PN-EN 61000-6-4 standard [13]. The measurement of electromagnetic disturbances was performed with the use of two available detectors:

- quasi-peak QP (quasi-peak value detector);

- average AV (average value detector).

The quasi-peak detector during the measurements allows to measure the maximum signal value after detection in the strictly defined measurement time. The average value detector allows to measure the average value level of the input signal samples for the specified measurement time - Fig. 4. 


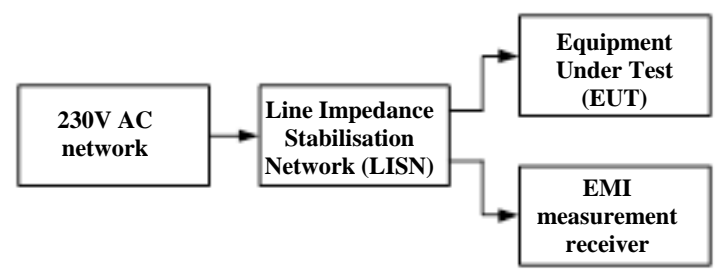

Fig. 4. Block diagram of the station for measuring the conducted disturbances

Figure 5 presents the measurement station providing the distance and location of individual measuring instruments in accordance with specific measurement procedures resulting from the standards.

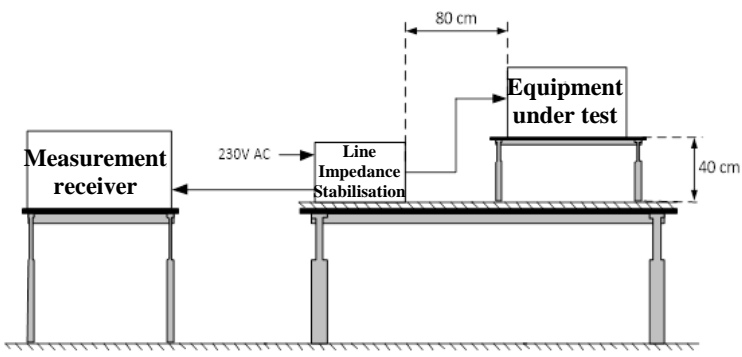

Fig. 5. Measurement of conducted disturbances of the information board

Figures 6 and 7 present the measurement results of conducted disturbances of the information board for $\mathrm{N}$ and $\mathrm{L}$ ports $230 \mathrm{~V}$ AC. The exceeding of limit values of the emission of disturbances specified in PE-EN 61000-6-4 standard was noticed in the frequency band: $13 \mathrm{MHz}-30 \mathrm{MHz}$ for $\mathrm{N} 230 \mathrm{~V} \mathrm{AC}$ port and $9 \mathrm{MHz}-30 \mathrm{MHz}$ for L $230 \mathrm{~V}$ AC port.

The causes of the excess of limit values of the emission of conducted disturbances resulted from the fact that the power and control cables inside the board were not shielded and they were conducted too close to the service card reader, which emitted interference. The electromagnetic disturbances entered through the field coupling to the cables. In order to eliminate unacceptable excess of the emission of conducted disturbances, the shielded power and control cables were used.

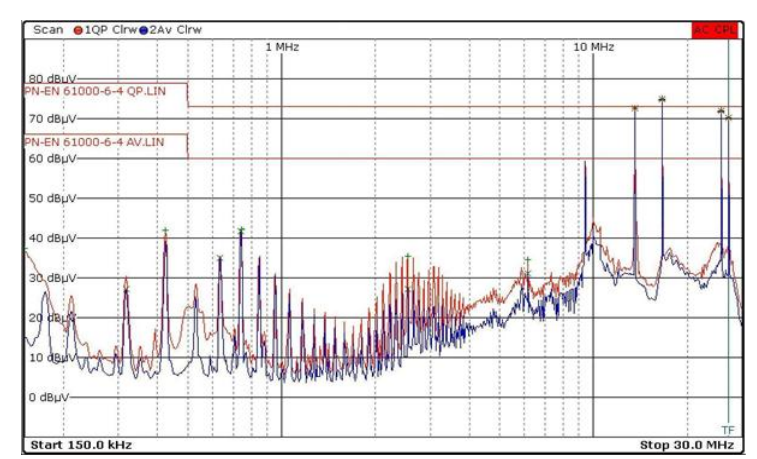

Fig. 6. Measurement of the emission of conducted disturbances of the information board: N 230V AC port

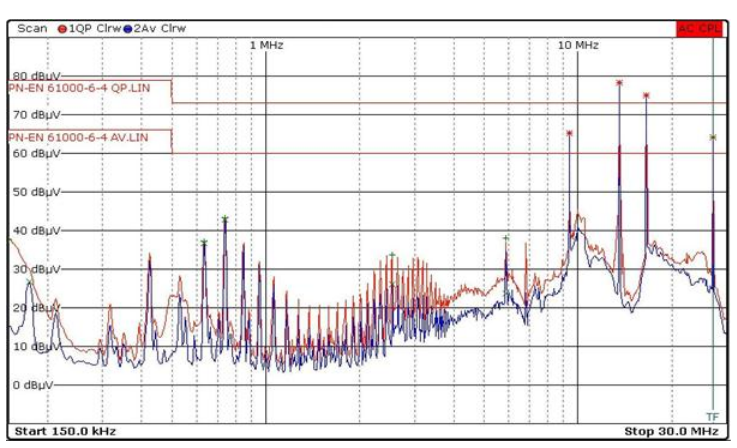

Fig. 7. Measurement of the emission of conducted disturbances of the information board: L 230V AC port

The power and control cable shields were connected on both sides with the reference potential bar of a given electronic device. Figures 8 and 9 present the test results of the emission of conducted disturbances after the use of shielded cables in the considered equipment.

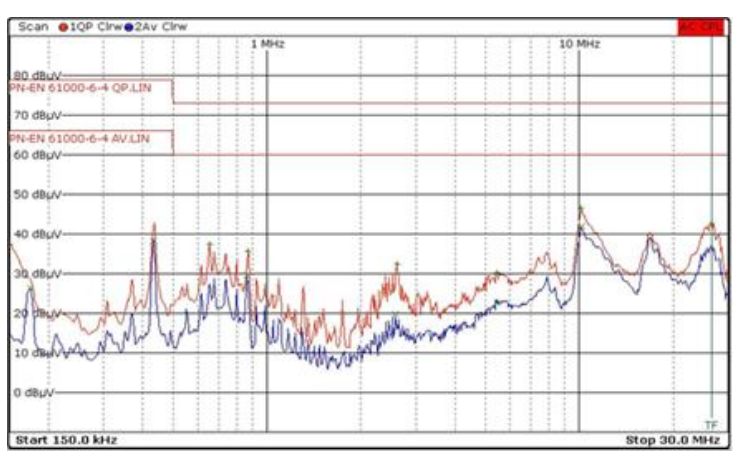

Fig. 8. Measurement of conducted disturbances of the information board: N 230

$\mathrm{V}$ AC port after shielding of cables

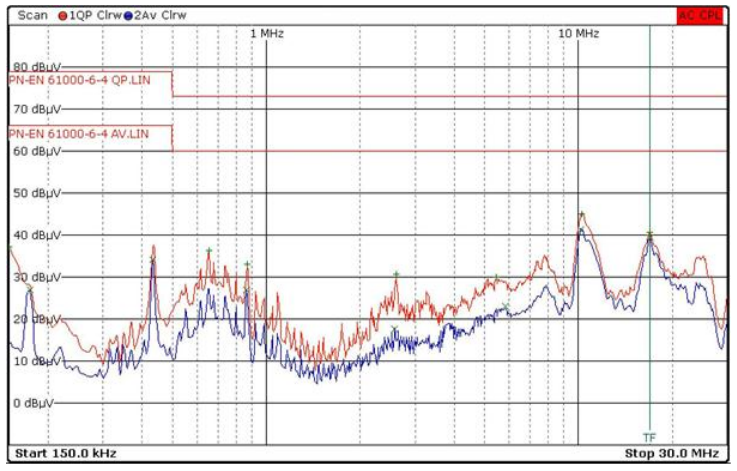

Fig. 9. Measurement of conducted disturbances of the information board: L 230

$\mathrm{V}$ AC port after shielding of cables

\section{EMISSION OF CONDUCTED DISTURBANCES BY THE SELECTED RAILWAY EQUIPMENT - STATIC CONVERTER}

The static converter mounted in the railway carriage is intended for supplying the carriage receivers with $110 \mathrm{~V}$ DC direct voltage. At the same time, it is used in the charging process of the 
carriage battery pack. The DC/DC static converter consists of the following elements: an input filter, an inverter, a transformer, a rectifier and an output filter. The principle of the inverter operation is the use of PWM digital modulation - pulse duration control. As a result of applying the abovementioned modulation in the converter voltage output waveform, the asymmetrical interference currents with a high frequency (variable pulse duration) are generated. The interference currents are transferred without attenuation to the converter output - i.e. load. The interference of the converter output waveform most often occurs in the frequency band from $3 \mathrm{MHz}$ to $30 \mathrm{MHz}$ and results from the limited range of changes in the repetition period of PWM modulated pulses. In order to reduce the above-mentioned interference in the output waveform, and thus, to eliminate the excess of permissible levels resulting from PN-EN-501213-2 railway standard [14], it is important to use the filters, which will direct the interference currents (of high frequency) to the common system ground point. It is also crucial to use the shortest connection to the system ground (impedance resistance to neutral), and also to avoid large areas of the ground loops. The ground loops should have the smallest possible area in order to minimise the impact of the interference electromagnetic fields on the cables. A beneficial element that can be applied in the elimination of interference is the use of loops between individual common grounds in the equipment. It reduced the common ground impedance between components and elements of the converter, and it reduces interference during its normal operation. Figures 10 and 11 present the test results of the emission of conducted disturbances of the DC/DC static converter, in which the ground wires were too long and were located so that they formed the ground loops with a large area.

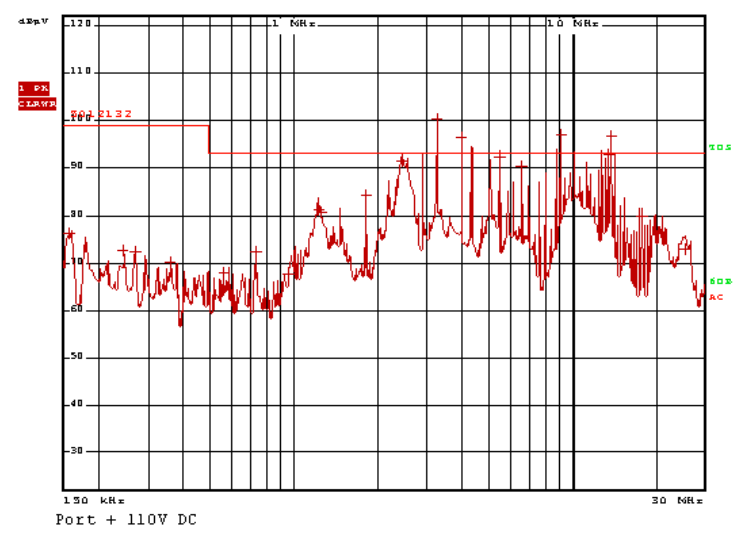

Fig. 10. Results of the emission of the converter conducted disturbances on $+110 \mathrm{~V}$ DC output ports

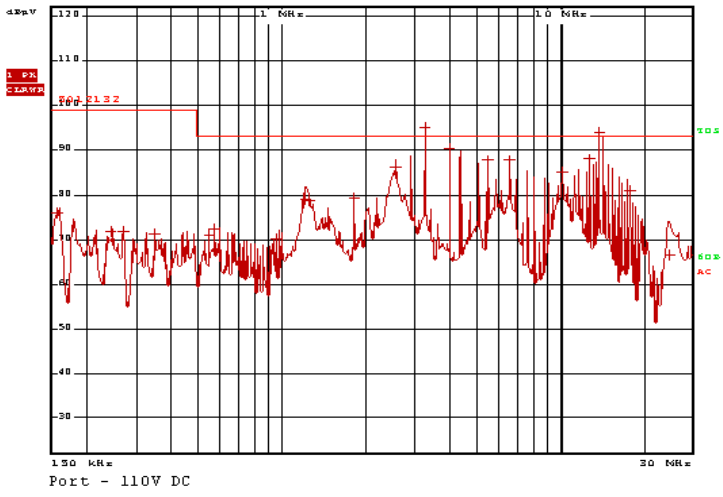

Fig. 11. Results of the emission of the converter conducted disturbances on $-110 \mathrm{~V}$ DC output ports

The basic technical parameters of the converter are shown in Table 1.

Table 1. Converter technical parameters

\begin{tabular}{|l|c|}
\hline \multicolumn{1}{|c|}{ Technical parameters } & Value \\
\hline Input voltage & $900 \mathrm{~V}$ DC \\
\hline $\begin{array}{l}\text { DC output } \\
\text { voltage/maximum power }\end{array}$ & $110 \mathrm{~V} \mathrm{DC} / 11 \mathrm{~kW}$ \\
\hline $\begin{array}{l}\text { DC output voltage } \\
\text { stability }\end{array}$ & $>1 \%$ \\
\hline Overall efficiency & $-25^{\circ} \mathrm{C} \div+45^{\circ} \mathrm{C}$ \\
\hline Operating temperature &
\end{tabular}

The block diagram of the measurement system for testing of conducted disturbances was presented in Fig. 12.

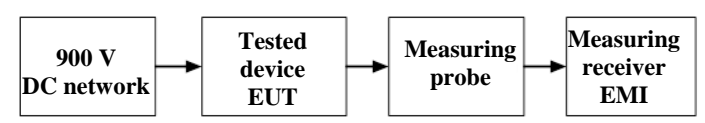

Fig. 12. Block diagram of the measurement system of conducted disturbances for the DC/DC converter on +/- 110V DC output ports

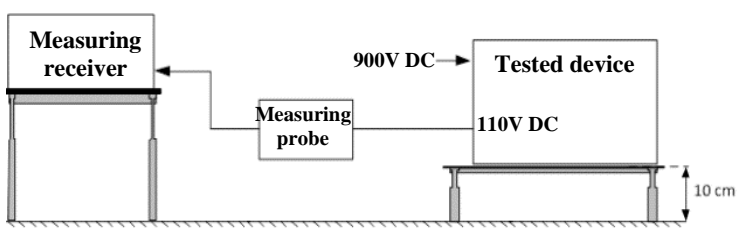

Fig. 13. The station for measuring the conducted disturbances for the DC/DC converter on $+/-110 \mathrm{~V}$ DC output ports

The measurements were carried out with the use of the quasi-peak detector (quasi-peak value detector). The static converter during testing of conducted disturbances was loaded with nominal power, i.e. $11 \mathrm{~kW}$. The measurements of conducted disturbances of the static converter were carried out in accordance with PN-EN 55016-2-1 standard [12]. The acceptable levels of interference were specified according to PN-EN 50121-3-2 standard [14]. Figures 10 and 11 show the excess of limit values in the frequency range from $3 \mathrm{MHz}$ to 
$15 \mathrm{MHz}$. In order to eliminate the conducted disturbances in the DC/DC static converter, the ground wires were maximally shortened to the grounds (the shortest possible path for the ground wires was used). In addition, the ground wires were used in order to create a loop between the connections of individual equipment grounds. The ground wires of the considered converter were too long to provide the efficient bonding between the equipment elements at low interference frequencies, which occurred in the equipment output signal. The low impedance connections between individual elements of the converter equipment at a high frequency significantly reduce the interference impact of external or internal, intentional or unintentional electromagnetic fields on the converter wires [15]. The ground loops occurring in the converter are not the same as the loops occurring between individual grounds in the considered equipment. The ground loops are very unfavourable due to the impact of internal and external interference, however, the loops between the ground connections in the converter are indicated and recommended for the suppression of interference. The results of the emission of conducted disturbance for the converter on $+/$ $110 \mathrm{~V} \mathrm{DC/DC}$ output ports after the performance of additional loops between grounds and after shortening of ground wires were presented in Figures 14 and 15.

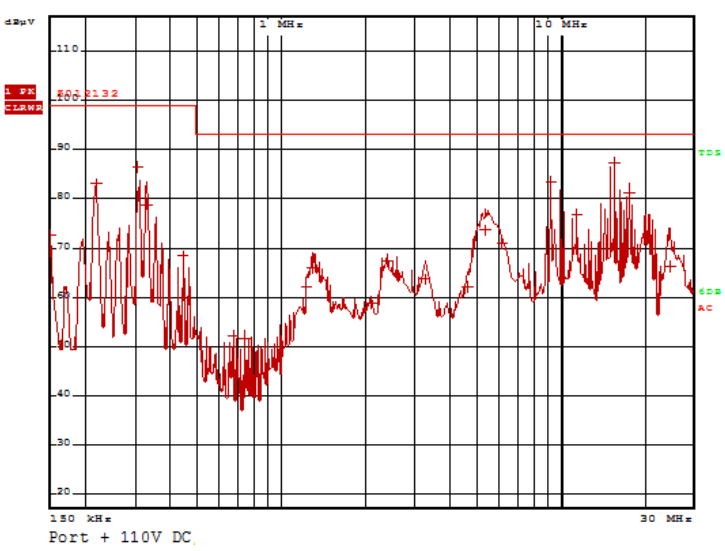

Fig. 14. The results of the emission of conducted disturbances in the converter on $+110 \mathrm{~V} \mathrm{DC}$ output ports after the introduction of structural changes related to ground connections

\section{CONCLUSION}

The article presented the issues related to the emission of conducted disturbances by the selected railway equipment, i.e. a static converter and an information board, which is located in the area of the railway station platforms $[1,8,23,27]$. Due to the electromagnetic compatibility provision, the

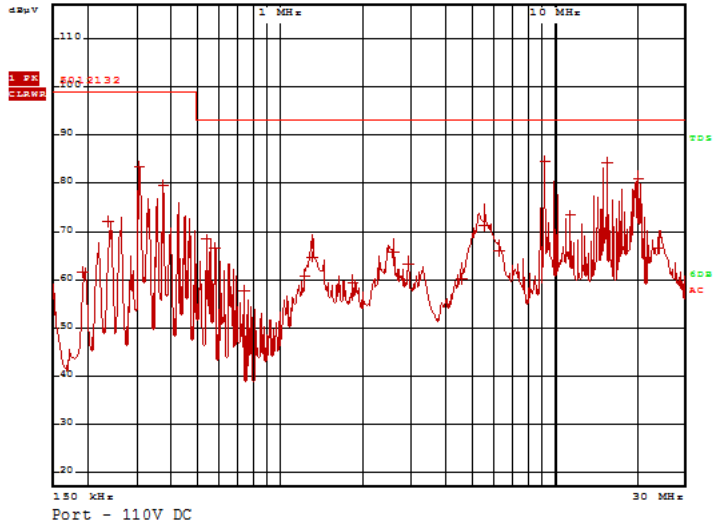

Fig. 15. The results of the emission of conducted disturbances in the converter on $-110 \mathrm{~V}$ DC output ports after the introduction of structural changes related to ground connections

vast railway area (platforms, railway station, signal box, etc.) is a very difficult environment, on which the stationary and mobile (intentional and unintentional) interference sources occur $[1,4,5,6$, $18,24]$. In case of the information board, for $\mathrm{N}$ $230 \mathrm{~V}$ AC and L $230 \mathrm{~V}$ AC power ports, there was the excess of PE-EN 61000-6-4 acceptable standard of the interference emission $[8,12,13,14,21]$. The increased level of conducted electromagnetic interference occurred in two frequency bands, i.e. $13 \mathrm{MHz}-30 \mathrm{MHz}$ for $\mathrm{N} 230 \mathrm{~V} \mathrm{AC}$ port, and $9 \mathrm{MHz}$ - $30 \mathrm{MHz}$ for $\mathrm{L} 230 \mathrm{~V}$ AC port. The reason for exceeding the limit values of the emission of conducted disturbances was an error resulting from the failure to use the shields for power and control cables inside the board. An additional factor that caused the occurrence of excessive levels of interference was the failure to maintain the appropriate cabling distance in relation to the service card reader of the information board, which emitted unacceptable interference. In order to eliminate the unacceptable emission of conducted disturbances, the proper shielded power and control cables were used. The power and control cable shields were connected on both sides with the reference potential bar of a given electronic device. The second device which was subjected to tests is DC/DC converter. The interference in the converter output waveform occurs in the frequency band from $3 \mathrm{MHz}$ to $30 \mathrm{MHz}$ and results from changes in the repetition period of PWM modulated pulses. In order to reduce the above-mentioned interference in the output waveform, and thus, to eliminate the excess of permissible levels resulting from PN-EN50121-3-2 railway standard [14], it is important to use the filters. The filtering systems allow to transfer the interference currents of high frequencies to the common system ground point. In the considered device, it is also important to use the shortest connections to the system ground - ground impedance. The ground loops should have the smallest possible area in order to minimise the impact of the interference electromagnetic fields on the cables in the internal devices. 


\section{REFERENCES}

1. Dyduch J, Paś J, Rosiński A. Basics of the operation of transport electronic systems. Publishing House of Kazimierz Pułaski University of Technology and Humanities in Radom, 2011.

2. Laskowski D, Łubkowski P, Pawlak E, Stańczyk P. Anthropotechnical systems reliability. In the monograph "Safety and Reliability: Methodology and Applications - Proceedings of the European Safety and Reliability Conference ESREL, 2014.

3. Rosiński A, Dąbrowski T. Modelling reliability of uninterruptible power supply units. Eksploatacja i Niezawodność - Maintenance and Reliability. 2013; 15(4): 409-413.

4. Pilo E. Power supply, energy management and catenary problems. WIT Press, 2010.

5. Rosiński A. Rationalisation of the maintenance process of transport telematics system comprising two types of periodic inspections. Published in "Proceedings of the Twenty-Third International Conference on Systems Engineering. 20151089.

6. Siergiejczyk M, Paś J, Rosiński A. Application of closed circuit television for highway telematics. Monograph: Telematics in the transport environment. 2012;329:159-165.

7. Billinton R, Allan RN. Reliability evaluation of power systems. New York: Plenum Press, 1996.

8. Perlicki K. Simple analysis of the impact of packet loss and delay on voice transmission quality. Journal of Telecommunications and Information Technology. 2002: 53-56.

9. Paś J, Duer S. Determination of the impact indicators of electromagnetic interferences on computer information systems. Neural Computing \& Applications. 2013; 23(7-8): 2143-2157. http://dx.doi.org/10.1007/s00521-012-1165-1.

10. Stawowy M. Model for information quality determination of teleinformation systems of transport. In: Proceedings of the European Safety and Reliability Conference ESREL 2014: 1909-1914.

11. PN-EN 55016-2-1 Requirements for measuring apparatus and methods for the measurement of radio disturbances and resistance to disturbances - Part 2-1: Methods for measuring the disturbances and resistance tests - Measurements of conducted disturbances.

12. PN-EN 61000-6-4 Electromagnetic compatibility (EMC) - Part 6-4: General standards - Emission standard for industrial environments.

13. PN-EN 50121-3-2 Railway applications Electromagnetic compatibility - Part 3-2: Rolling stock - Apparatus.

14. Charoy A. Interference in electronic devices, Vol. 2, Scientific and Technical Publishing. Warsaw. 2000.

15. Paś J, Rosiński A. Selected issues regarding the reliability-operational assessment of electronic transport systems with regard to electromagnetic interference, - Maintenance and Reliability, 2017; 19 (3): 375-381, http://dx.doi.org/10.17531/ein.2017.3.8.

16. Restel FJ. The Markov reliability and safety model of the railway transportation system Safety and Reliability: Methodology and Applications Proceedings of the European Safety and Reliability Conference, ESREL 2014: 303-311

17. Paś J. Wireless control process technical exploitation facility. Journal of KONBiN. 2017; 41:107-128. http://dx.doi.org/10.1515jok-2017-0006
18. Wang L (ed.). Modeling and control of sustainable power systems. 2012.

19. Kuchta M, Siergiejczyk M, Paś J. Automatic system for measuring shifts and deformation of dental prostheses. Journal Of Vibroengineering. 2016;18(7): 4720-4728.

20. Ogunsola A, Mariscotti A. Electromagnetic compatibility in railways. Analysis and management. Springer-Verlag, 2013.

21. Paś J. Operation of electronic transportation systems. Publishing House University of Technology and Humanities, Radom, 2015.

22. Garmabaki AHS, Ahmadi A, Mahmood YA, Barabadi A. Reliability modelling of multiple repairable units. Quality and Reliability Engineering International 2016; 32(7): 2329-2343. http://dx.doi.org/10.1002/qre.1938

23. Verma AK, Ajit S, Karanki DR. Reliability and safety engineering. London, 2010.

24. Billinton R, Allan RN. Reliability evaluation of power systems, Plenum Press, New York, 1996.

25. Soliman SA, Mantawy AH. Modern optimization techniques with applications in electric power systems. Springer Science+Business Media, 2012.

26. Wierzbicki S. Diagnosing microprocessor controlled systems. Teka Komisji Motoryzacji i Energetyki Rolnictwa, 2006; VI:183-188.

27. Paś J, Rosiński A, Wiśnios M. Majda-Zdancewicz E, Łukasiak J. Electronic security systems. Introduction to the laboratory. Military University of Technology, Warsaw, 2018.

Received 208-03-06

Accepted 2018-06-05

Available online 2018-07-03

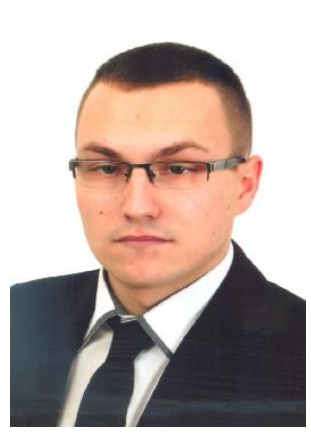

Kamil BIALEK MEng. Electronics and telecommunications engineer in the Faculty of Electronic of Military University of Technology in Warsaw. His current research interests include electromagnetic compatibility, digital and analogy circuits, railway transport and projecting.

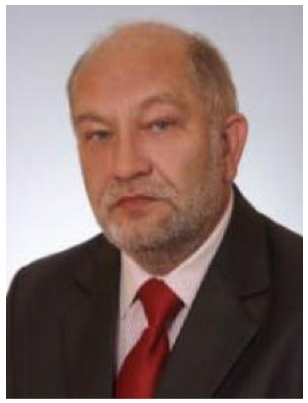

Jacek PAŚ Ph.D., D.Sc., Eng., professor of Military University of Technology - Division Electronic Systems Exploitations Manager, scientific interests (electromagnetic compatibility, analog circuits, reliability, low frequency noise, exploitation, diagnostics, projecting) are problems connected with comprehended wide of the safety both for stationary as well as for movable objects. He is the author of three books and more than 200 articles. His research interests include also environmental studies of electromagnetic the range at low frequencies at (electrosmog). 